\title{
EDITORIAL
}

\section{¿ES CONTROLABLE LA COVID-19?}

Se estima que nuestro planeta tiene una edad de 4.500 millones de años. El origen de los virus posiblemente data de 2.000 millones de años atrás, durante los cuales se han adaptado a diversos hospederos del mundo microbiano, vegetal y animal para sobrevivir y reproducirse como especie. Y ahora nos concierne los que están afectando a la especie humana, adaptándose a los cambios ecológicos que han ocurrido desde hace 2 millones de años. En este contexto, el cambio de vida nómade a sedentaria ocurrido 10.000 años AC, podría representar el inicio de la infectología. ¿Serán capaces los avances de la civilización, la ciencia y la tecnología de revertir hechos de la naturaleza que recién estamos descubriendo y tratando de superar en nuestra vida actual?

Se han registrado pandemias de bacterias y virus desde los primeros siglos de nuestra era. Ellas -de origen bacteriano y viral- han sido altamente letales, causando millones de muertes. En los últimos siglos han prevalecido aquéllas generadas por virus ARN, como los virus influenza, que representan el referente de comparación con la pandemia de coronavirus actual.

Los virus ARN usan la variabilidad como mecanismo de sobrevivencia como especie. Muchos poseen una ARN polimerasa "infiel" en el proceso de replicación de su genoma, cometiendo aproximadamente un error por cada 10.000 bases que copian, los cuales no disponen de un sistema molecular corrector, como sucede en los virus ADN. La acumulación de estas variaciones implicaría aparición de mutaciones que favorecen o deterioran la especie descendiente. Este fenómeno ocurre al azar.

Los virus influenza son muy buenos ejemplos de variabilidad antigénica, y por eso la historia lo muestra como el más frecuente generador de pandemias en la humanidad. La OMS ha debido organizar un sistema mundial de vigilancia de la influenza para caracterizar las cepas circulantes, la emergencia de variantes y la sensibilidad a las vacunas y antivirales desarrollados.

Los coronavirus tienen semejanza estructural con los virus influenza, en el sentido que tienen genoma de ARN y un manto lipoproteico, aunque no poseen un genoma fraccionado que facilita aún más la variabilidad. Afortunadamente para nosotros, el SARS-CoV-2 posee un sistema corrector de errores de la polimerasa, aunque no parece ser tan eficiente como el de virus ADN. La estrategia de los virus respiratorios para mantenerse como especie es simple. Contagian eficientemente vía aérea en forma directa por gotitas de saliva expelidas a distancias de 1-2 mts. al hablar, gritar, toser, estornudar o indirecta por las gotas pequeñas que conforman aerosoles que se expanden a mayor distancia. Además, estos virus producen infecciones asintomáticas que también transmiten y algunos casos lo hacen desde pocos días antes de manifestar síntomas. Estas estrategias dificultan su detección y control: al virus le basta con propagarse escasamente en forma de infección aguda, para mantenerse como especie... su único objetivo.

El objetivo actual de la humanidad de lograr controlar o eliminar la pandemia de SARS-CoV-2 es un desafío histórico, pues sólo lo ha logrado con el SARS coronavirus de 2003, infección que aunque bastante virulenta, era poco transmisible. La OMS demoró 10 años (1967-1977) en erradicar la viruela, enfermedad clínicamente sintomática, con una vacuna viva atenuada. La campaña de control de la poliomielitis con una vacuna viva atenuada empezó en 1988 y ha erradicado los virus poliomielitis 2 y 3, quedando todavía pocos casos de poliomielitis 1 en Asia. Con el sarampión y la rubéola sólo se ha logrado eliminarlos temporalmente de algunas regiones. En el intertanto han surgido pandemias de virus ARN -Dengue, Fiebre amarilla, Zika, HIV/SIDA, influenza A- cuyo control ha sido infructuoso.

\section{Dr. Luis Fidel Avendaño C.}

Profesor Titular-Universidad de Chile.

Miembro Honorario Academia Chilena de Medicina.

lavendan@uchile.cl 
Las vacunas son las armas más eficientes en salud pública después del agua potable. El control de muchas infecciones bacterianas y virales se ha logrado gracias a su desarrollo. Este proceso es muy estricto y financieramente costoso y siempre debe pasar por etapas de evaluación en laboratorio, animales y en seres humanos. En estas últimas se evalúa sucesivamente la seguridad (Fase 1) y antigenicidad (Fase 2); luego se hace la Fase 3, que es una forma experimental que compara en forma ciega un grupo vacunado versus uno de control, para determinar la "eficacia" del candidato a vacuna. Si se aprueba, se licencia y se fabrica para usarlo masivamente en la población, lo que ratifica su "efectividad". En cada etapa se revalida la seguridad, considerando los efectos secundarios en poblaciones más numerosas. De esta forma, la evaluación progresiva por comités independientes garantiza su uso internacional.

Ante epidemias por virus respiratorios, aparte de vacunas disponibles, se recurre a las medidas de supresión/ mitigación. Estas son ampliamente conocidas porque mientras no se desarrollen vacunas representan la única arma para el control de la epidemia, especialmente ante un agente nuevo. Hay muchas estrategias, muy variadas y su aplicabilidad tiene problemas de cumplimiento. Entre ellas se mencionan el uso de mascarillas, distanciamiento físico, lavado frecuente de manos y aseo de lugares contaminados; aislamiento de enfermos y contactos, cuarentena; la disminución de la movilidad, restricciones de viajes por aire, tierra, mar, el cierre de fronteras; la reconversión de hospitales públicos y privados, de salas de distintas categorías para atención específica, incluyendo personal, ambulancias y otros elementos necesarios, etc.

Desgraciadamente no hay una forma precisa de valorar el cumplimiento y la eficacia de cada una de ellas y se supone que hay efecto sumatorio entre ellas. Y eso depende del comportamiento de la población. Los epidemiólogos y el público que cree entender la patogenia de las pandemias suele criticar las medidas adoptadas por la autoridad. Por ejemplo, el uso de la cuarentena -una medida muy dura social y económicamente- es un arma de doble filo, porque si bien reduce el contagio en la comunidad, puede aumentarlo en los hogares al concentrar contaminadores en espacios cerrados.

Por eso, si bien es necesario combinar la vacunación con medidas de mitigación comunitaria, el inmenso aporte de la ciencia al lograr desarrollar aceleradamente vacunas en múltiples plataformas es el arma que permitiría controlar -no eliminar- la pandemia por SARS-CoV-2. Lo más probable es que no se logre alcanzar un nivel de inmunidad de rebaño mundial por vacunas más infección natural (63\%), pues recién van 190 millones de contagiados oficialmente de una población de 7.700 millones (2,5\%). Así, el SARS-CoV-2 se quedaría como una endemia de bajo nivel, como ha sucedido con el virus influenza A H1N1, cuyas primeras apariciones datan de 1918.

Aún queda mucho trabajo: expandir el uso de vacunas para hoy y mañana, incluyendo la respuesta a muchos dilemas que surgen cada día. Una visión optimista basada en el enorme desarrollo científico actual nos permite augurar que las soluciones vienen con el trabajo cooperativo de científicos desarrollando antivirales, vacunas, inmuno reguladores, con clínicos y epidemiólogos estudiando su efectividad. Ya está ocurriendo

\section{El autor declara no presentar conflicto de interés.}

\section{REFERENCIAS}

1. Visión histórica de la Virología. En: Avendaño LF, Ferres M, Luchsinger V, Spencer E. Virología Clínica, 2ª Ed Mediterráneo. 2018. pp 15-19.

2. Carrol D, Daszac P, Wolfe $N$ et al. The Global Virome Project. Science 2018. 359(6378).872-874. DOI: 10.1126/science.aap7463

3. LePan N. Visualizing History of Pandemics. Visual Capitalist. March 14, 2020. https://www. visualcapitalist.com/history-of-pandemics-deadliest

4. Moriyama M, Hugentobler WJ, Iwasaki A. Seasonality of respiratory viral infections. Annu Rev Virol 2020.7:2.1-2.21. Https:// doi.org//10.1146/annurev. virology- 012420

5. Dance A. The incredible diversity of viruses. Nature 2021:595: 22-25

6. Chaccour C, Casellas A, Blanco-Di Matteo A, Piñeda I, Fernandez-Montero A, et. al. The effect of early treatment with ivermectin on viral load, symptoms and humoral response in patients with non-severe COVID-19: A pilot, double-blind, placebo-controlled, randomized clinical trial. https://doi.org/10.1016/j. eclinm.2020.100720 